\title{
Estimating the Efficiency of Transportation Energy Consumption based on Railway Infrastructure and Travel behavior Characteristics
}

\author{
Hyunsu Choi ${ }^{\dagger}$, Dai Nakagawa*, Ryoji Matsunaka*, Tetsuharu Oba* and Jongjin Yoon*
}

\begin{abstract}
In recent years, energy consumption in the transportation sector by expanding motorization continues to increase in almost every country in the world. Moreover, the growth rate of the transportation energy consumption is significantly higher than those of the civilian and industrial sectors. Therefore, every country strives to reduce its dependence on private transport, which is the main contributor to the transportation energy consumption. In many countries, concepts such as Transit Oriented Development (TOD) or New Urbanism, which controls road traffic by increasing the proportion of the public transportation significantly, have been implemented to encourage a modal shift to public transport. However, the level of change required for eliminating environmental problems is a challenging task. Minimizing transportation energy consumption by controlling the increase of the traffic demand and maintaining the level of urban mobility simultaneously is a pressing dilemma for each city. Grasping the impact of the diversity of the urban transport and infrastructure is very important to improve transportation energy efficiency. However, the potential for reducing urban transportation energy consumption has often been ineffectively demonstrated by the diversity of cities. Therefore, the accuracy of evaluating the current efficiency rate of the urban energy consumption is necessary. Nevertheless, quantitative analyses related to the efficiency of transportation energy consumption are scarce, and the research on the current condition of consumption efficiency based on international quantitative analysis is almost nonexistent. On the basis of this background problem definitions, this research first built a database of the transportation energy consumption of private modes in 119 cities, with an attempt to reflect individual travel behaviors calculated by Person Trip data. Subsequently, Data Envelopment Analysis (DEA) was used as an assessment method to evaluate the efficiency of transportation energy consumption by considering the diversity of the urban traffic features in the world cities. Finally, we clarified the current condition of consumption efficiency by attempting to propose a target values for improving transportation energy consumption.
\end{abstract}

Keywords : Efficiency of transportation energy consumption, Global cities database, Railway infrastructure, Travel behavior, Data Envelopment Analysis (DEA), Person trip data (PT data)

\section{Introduction}

In recent years, in each city in the world, people's travel range has expanded due to motorization in parallel with economic development, and the urban structure is changing with suburbanization processes. Moreover, the trans-

\footnotetext{
Corresponding author: Department of Rail research, The Korea Transport Institute, Goyang-si, Korea

E-mail : hs_choi@koti.re.kr

Department of Urban Management, Kyoto University, Kyoto, Japan

(c) The Korean Society for Railway 2013

http://dx.doi.org/10.7782/IJR.2013.6.2.033
}

portation energy consumption is increasing, resulting in serious urban problems such as air pollution and excessive energy consumption in the urban environment (Nakamura et al., 2004).

New city planning methods and management of technical developments for traffic systems or cutting transportation energy consumption have developed. Since 1970, many planning techniques and research projects have aimed to develop urban structure based on the concept of sustainable development. In Europe, the concept of the compact city is well-received and the urban planning related to constructing efficient urban space is underway and also, in Japan, compact cities have even been speci- 
fied as a basic policy of urban planning (Taniguchi et al., 2008). Since suburbanization with low population density and increasing trip length are connected with increasing transportation energy consumption (Choi et al., 2011), it is indispensable to control an individual's travel behavior for reducing transportation energy consumption, and it is important to understand the urban-transport factors according to the development of transport infrastructure. Especially, the rail infrastructure in cities contributes to reducing transportation energy consumption in general. However, the size of effects on reducing transportation energy consumption could be different from cities at the condition of rail development. Therefore, it is critically important not only to estimate the transportation energy consumption of a city, but also to clarify how the relationship between transportation energy consumption and individual travel behaviors differ according to the rail development. In order to realize the environmentally sustainable transport (EST), it becomes quite important to mitigate environmental load from the transport sector as well as to maintain the level of mobility. Because the mobility policies often come into conflict with the environmental ones, the policy decision makers need to find a way to solve the exclusiveness between these two policies (Yoshino et al., 2010). We endeavor to clarify the efficiency of transportation energy consumption from the various urban-transport factors with DEA(Data Envelopment Analysis) cost efficiency model focusing on the transport system. In this context, Feng et al., (2007) and Ahmad et al., (2009) evaluated the energy efficiency in transport sector by using SFA(Stochastic Frontier Analysis) or DEA. Moreover, Yoshino et al., (2010) applied DEA to measure the efficiency of energy consumption at a given level of mobility in public and private transport system. They defined the efficiency of transportation energy consumption with the ratio between energy consumption and the average travel speed of each mode. Nevertheless, these studies used different approaches, they commonly defined the energy efficiency as a ratio of transport index (input) and environmental index (output) or defining mobility with only trip speed is not sufficient enough to reflect the actual travel behavior. The above definitions remain an important problem which does not consider the diversity of transport systems inherent in each city. Obviously the energy efficiency must be influenced by several factors. The weight of each factor could also vary depending on the level of infrastructure development, transport investment and so on. However, most of the existing studies put equal weight on all factors. Meanwhile, the economic level of city has an effect on the relationship between urban density and characteristics of travel behaviors. Choi et al., (2012) clarified that despite similarities in urban structure, the economic level of the city influences modal choice and the characteristics of travel behaviors which impacts transportation energy consumption and infrastructure development. However, their research did not consider how the condition of transportation infrastructure (i.e., railway system) could have effects on the propensity to transportation energy consumption or its efficiency related to economic feasibility.

Therefore, we defined the efficiency of transportation energy consumption as creating more economical value with less environmental impact of Private Motorized Modes (PMM) by imposing adjusted weights. Here, we consider that GRDP is the economical outcome of the traffic activities generated by people who participate in social economical activities in a city. And, daily trip number of public modes and PMM also can be thought of as the results of traffic activities purposing production activity in a city. In this context, the outputs reflect the economical concept attributed to traffic activities.

\section{Definition of Trip in this Research and the Estimation Method of Transportation Energy Consumption}

\subsection{Definition of trip}

From the viewpoint that reduction of the transportation energy consumption can be obtained by controlling individual modes of transportation appropriately, the current research extracted data for trips made by private motorized modes (PMM; passenger car, motorcycle, and taxi). Hence, the freight traffic, from which the travel characteristics are difficult to grasp Person Trip data (here in after PT), was excluded from this research. In addition, the trip mode used in trips with the longest trip time in a complete trip was treated as the representative mode for the trip. Furthermore, extracted trips below $4 \mathrm{~km} / \mathrm{h}$ on the representative mode were excluded from target trip as walking and maximum trip speed is set as $100 \mathrm{~km} / \mathrm{h}$. Moreover, this research restricted a trip length within $150 \mathrm{~km} /$ trip for considering maximum diameter of the urban area targeted in the current research. As for counting the passenger numbers on PMM trips on the Japanese PT, the passenger number cells are sometimes left blank or "N/A", despite the presence of a driver. In this case, the PT information was counted as " 1 " for the driver. Finally, the trips are extracted from the condition that trips made with at least on extremity (origin and/or destination) inside the urban area and based on the household inside the urban area. However, the US cities are only considered household constraint due to the limitation on data contents of the PT 
data from NHTS (National Household Travel Survey).

In this research, trips that follow the above constraint conditions were extracted from the total trip made within the target area and used to estimate the transportation energy consumption.

\subsection{Estimation method for transportation energy consumption by private motorized modes}

The most standard method to estimate transportation energy consumption is to measure the total consumption of fuel in a city by applying statistical data of the total amount of the sold fuel, and then converting the total consumed sold fuel into energy per unit amount of fuel (Kenworthy and Laube, 1999: Morimoto and Koike, 1995). In addition, it is difficult to determine the supplying and consumption districts for fuel (Matsuhashi et al., 2004). Alternatively, in Japan, as an estimation method of transportation energy consumption, the integrating energy intensity and trip length is generally used. Although the former is suitable for grasping a discharge of the total amount or total evaluation of the measure against fuel, there are limitations regarding the vehicle type and the evaluation of travel behavior in an independent trip (Morimoto and Koike, 1995). Since the latter may differ in the estimation value of energy intensity with various statistical materials, comparison between cities not straightfoward.

This research exploits the data on traffic behavior for every individual trip based on the PT data and the formula for fuel efficiency of a gasoline vehicle considering the travel speed defined from measurement of the "Sdsdynamo" experiment conducted by the ministry of the environment in Japan. From this data and estimation formula, the transportation energy consumption is calculated using equation (1).

$$
E_{k}=\left(\frac{\sum_{i}^{n} T_{i} \cdot I_{i} \times 365}{O_{k}}\right) / P_{k}
$$

$E_{k}=$ Annual transportation energy consumption by private motorized modes per capita in city $k$ (MJ per capita)

$T_{i}=$ Transportation energy consumption by private motorized modes in single trip $i$ (MJ)

$\left(i=1, \cdots, n^{k} ; n^{k}\right.$ : the number of trip sample in city $k$ )

$P_{k}=$ Urban population in city $k$

$I_{i}=$ Expansion coefficient of each trip $i$

$O_{k}=$ Average occupancy of passenger car in city $k$

Moreover, in equation (1), the transportation energy consumption by private motorized modes in single trip i can be calculated using equation (2).

$$
T_{i}=F C_{\left(V_{i}\right)} \cdot H V \cdot L_{i}
$$

$H V=$ Average calorific value of gasoline $(\mathrm{MJ} / \mathrm{L})$

$F C_{\left(V_{i}\right)}=$ Fuel efficiency of a vehicle on trip $i$ at speed $v$ $(\mathrm{cc} / \mathrm{km}$; Motorcycle is assumed to have a half the efficiency of a car and vehicle is assumed to be gasoline vehicle; Refer to notes for the background)

$$
\begin{aligned}
& L_{i}=\text { Trip length of trip } i(\mathrm{~km}) \\
& V_{i}=\text { Trip speed of trip } i \text { by private motorized modes }
\end{aligned}
$$
$(\mathrm{km} / \mathrm{h})$

However, in this research, the private motorized modes are limited to passenger cars, taxi, and motorcycles. Fuel efficiency of private motorized modes on trip $i$ at speed $v$ is obtained using equation (3) (Oshiro et al., 2001).

$$
F C_{\left(V_{i}\right)}=\left[829.3 / V_{i}\right]-0.8572 V_{i}+0.007659 V_{i}^{2}+64.09
$$

The model parameters in equation (3) are inferred from the results of the research conducted in at the Japanese research institute. However, the model parameters can be customized to country or vehicle type. The results in equation (3) are based on the use of a passenger car.

Finally, the renewal estimation method becomes a function of the vehicle speed in an individual trip. For cases where the PT data has insufficient trip information, the improved method is a form of equation (1). For European cities and several Korean cities, travel behaviors such as average vehicle speed, average trip length, and modal share of private motorized modes, are representative values due to limitations in gathering international data. Therefore, we evaluated an alternative estimation method for cases lacking these data using equation (4).

$$
E_{k}=P_{k} \cdot G_{k} \cdot \gamma_{k} \cdot l_{k} \cdot e
$$

$E_{k}=$ Transport energy consumption in city $k(\mathrm{MJ})$

$P_{k}=$ Population in city $k$ (person)

$G_{k}=$ Average daily trip number in city $k$ (trip)

$\gamma_{k}=$ Modal share of private motorized modes in city $k(\%)$

$l_{k}=$ Average trip length in city $k(\mathrm{~km} /$ trip$)$

$e=$ Intensity of energy consumption $(\mathrm{MJ} /$ person $\cdot \mathrm{km})$

This is useful for estimating transportation energy consumption based on average trip length for private motorized modes per day, average number of daily trips in city $k$, modal share of private motorized modes of transportation, and population in city $k$. Additionally, the average speed of the private motorized modes and the intensity of heat combustion are multiplied to estimate fuel efficiency of the vehicle. If a city has its own PT data, the renewed estimation method is promising. However, when this model cannot be applied due to a lack of PT data, the alternative method can be improved by incorporating the vehicle speed. This improvement is realized by changing the intensity factor e in equation (4) into $e_{k}$. The estimation 
Table 1 Definition of data in this research

\begin{tabular}{|c|c|c|c|}
\hline No & Indicator & Unit & Definition of data \\
\hline 1 & Urban density & inhabitants/ha & -Ratio between the population and urban surface area \\
\hline 2 & GRDP & \$/inhabitants & -Ratio between the GRDP of the urbanized area and its population. \\
\hline 3 & $\begin{array}{l}\text { Daily trips by PMM or } \\
\text { Public modes }\end{array}$ & $\begin{array}{l}\text { Trip/ } \\
\text { day/ } \\
\text { inhabitants }\end{array}$ & $\begin{array}{l}\text { Characterized as: } \\
\text {-Tripsmadebypersonsover5yearsofagewhoresidein the urbanized area } \\
\text {-Trips with at least one extreme (origin and/or destination) inside the urbanized area } \\
\text {-Allreasonsfortravelandalltransportmodes,motorized,orotherwise } \\
\text {-Trips on foot or bicycle are not included } \\
\text {-Tripsmadeusingseveralmodesarecountedasonetripandassignedtoa "primary mode" }\end{array}$ \\
\hline 4 & $\begin{array}{l}\text { Average trip speed of } \\
\text { PMM or Public modes }\end{array}$ & $\mathrm{km} / \mathrm{h} /$ trip & $\begin{array}{l}\text {-With reference to trips defined by indicator 3, including automobiles, motorcycles, and } \\
\text { taxis, as PMM, including bus, metro, tram, railway transit on public as Public transport. } \\
\text {-The actual trip speed is sought }\end{array}$ \\
\hline 5 & $\begin{array}{l}\text { Average trip distance of } \\
\text { PMM or Public modes }\end{array}$ & $\mathrm{km} /$ trip & $\begin{array}{l}\text {-With reference to trips defined by indicator } 3 \text {, including automobiles, motorcycles, and } \\
\text { taxis, as PMM, including bus, metro, tram, railway transit on public as Public transport. } \\
\text {-The actual distance is sought, not a straight line distance } \\
\text {-Inthiscase,tripsextendingbeyondtheurbanizedarea are considered. }\end{array}$ \\
\hline 6 & $\begin{array}{l}\text { Average trip duration of } \\
\text { Public modes }\end{array}$ & $\min /$ trip & $\begin{array}{l}\text {-With reference to trips defined by indicator } 3 \text {, including bus, metro, tram, railway } \\
\text { transit on public as Public transport. } \\
\text {-The actual trip duration is sought }\end{array}$ \\
\hline 7 & Total metro length & $\begin{array}{c}\mathrm{m} / 1000 \\
\text { inhabitants }\end{array}$ & -The computation of the length of metro in the urban area \\
\hline 8 & Total tram length & $\begin{array}{c}\mathrm{m} / 1000 \\
\text { inhabitants }\end{array}$ & -The computation of the length of tram in the urban area \\
\hline 9 & Total monorail length & $\begin{array}{c}\mathrm{m} / 1000 \\
\text { inhabitants }\end{array}$ & -The computation of the length of monorail in the urban area \\
\hline 10 & Total road length & $\begin{array}{c}\mathrm{m} / 1000 \\
\text { inhabitants }\end{array}$ & $\begin{array}{l}\text {-The computation of the length of road in the metropolitan area considers all roads } \\
\text { open to public traffic located in the metropolitan area. }\end{array}$ \\
\hline
\end{tabular}

method for the factor e can be revised by

$$
e_{k}=F C_{\left(V_{k}\right)} \cdot H V
$$

$e_{k}=$ Intensity of energy consumption of city $k$ (MJ/ person $\cdot \mathrm{km}$ )

$F C_{\left(V_{k}\right)}=$ Fuel efficiency of a vehicle at average speed $V_{k}(\mathrm{cc} / \mathrm{km})$

$V_{k}=$ Average vehicle speed in city $k(\mathrm{~km} / \mathrm{h})$

\section{Database on Transportation Energy Consumption of Cities in the World}

\subsection{Target metropolitan areas}

In this research, the statistical data for each area was collected from 119 metropolitan areas in 38 countries. The data was originally collected by research institutes around the world. (See for the official names of the institutes listed in the notes) to ensure the objectivity that cities and traffic characters of metropolitan areas with similar population capacities were compared, the target cities in this study were defined as metropolitan areas with a minimum population of 800,000 .

\subsection{Definitions and calculation methods of travel behavior}

Table 1 defines the data definition used in the current research and the origin of the data. The definition of the annual transportation energy consumption for the PMM is explained in Chapter 3. Since this research employs PT data, various data regarding different properties of travel behavior can be extracted. The definition of calculation methods agrees with the definition of data possessing bounded means.

To estimate transportation energy consumption, four main travel characteristics are considered: trip length, trip speed, daily trip number, and modal share of private motorized modes, as mentioned in the previous chapter. However, the data fields of the person trip data differ by country. It should be noted that the calculation method of travel behavior in Table 2 differs slightly by country and depends on how the person trip data was configured. Moreover, due to the limitations in the data from European cities and some Korean cities, travel behaviors were estimated throughout the whole urban area using the cities average of trip values on travel behavior. 
Estimating the Efficiency of Transportation Energy Consumption based on Railway Infrastructure and Travel behavior Characteristics

Table 2 Calculation methods to explain travel behavior data

\begin{tabular}{|c|c|c|c|c|}
\hline $\begin{array}{l}\text { Data on travel } \\
\text { behavior }\end{array}$ & $\begin{array}{l}\text { Applied cities } \\
\text { (Num. of sample cities) }\end{array}$ & Equations & $\begin{array}{l}\text { Data resources } \\
\text { (Num. of data } \\
\text { source) }\end{array}$ & Note \\
\hline \multirow{4}{*}{ Trip length $(\mathrm{km})$} & Korea (9) & \multirow[b]{2}{*}{$L_{k}=V_{k} \cdot\left(\sum_{1}^{n}\left(I_{i}^{r, k} \cdot D_{i}^{r, k}\right) / \sum_{1}^{n} I_{i}^{r, k}\right)$} & $:(4)$ & \multirow{4}{*}{$\begin{array}{l}\text { Suwon, } \\
\text { Sungnam in } \\
\text { Korea are } \\
\text { followed the } \\
\text { equation of } \\
\text { Europe. }\end{array}$} \\
\hline & $\begin{array}{l}\text { Developing } \\
\text { countries (14) }\end{array}$ & & $\overline{:(2),(3)}$ & \\
\hline & $\begin{array}{c}\text { Europe (31), } \\
\text { Wealthy Asian (4) }\end{array}$ & $L_{k}$ & (2) & \\
\hline & $\begin{array}{l}\text { Japan (14) } \\
\text { USA (46) }\end{array}$ & $L_{k}=\left(\sum_{1}^{n}\left(I_{i}^{r, k} \cdot l_{i}^{r, k}\right) / \sum_{1}^{n} I_{i}^{r, k}\right)$ & (3) & \\
\hline \multirow{4}{*}{$\begin{array}{l}\text { Vehicle speed } \\
\qquad(\mathrm{km} / \mathrm{h})\end{array}$} & Korea (9) & \multirow[b]{2}{*}{$V_{k}$} & (4) & \multirow{4}{*}{ N/A } \\
\hline & $\begin{array}{l}\text { Developing } \\
\text { countries (14) }\end{array}$ & & (2) & \\
\hline & $\begin{array}{c}\text { Europe (31), } \\
\text { Wealthy Asian (4) }\end{array}$ & $V_{k}=L_{k} / D_{k}$ & (2) & \\
\hline & $\begin{array}{l}\text { Japan (14) } \\
\text { USA (46) }\end{array}$ & $V_{k}=\left(\sum_{1}^{n}\left(I_{i}^{r, k} \cdot l_{i}^{r, k}\right) / \sum_{1}^{n} I_{i}^{r, k}\right) /\left(\sum_{1}^{n}\left(I_{i}^{r, k} \cdot D_{i}^{r, k}\right) /\left(\sum_{1}^{n} I_{i}^{r, k}\right)\right)$ & (3) & \\
\hline \multirow{4}{*}{$\begin{array}{l}\text { Number of daily } \\
\text { trips } \\
\text { (trips/day/person) }\end{array}$} & $\begin{array}{c}\text { Europe (31), } \\
\text { Wealthy Asian (4) }\end{array}$ & $T_{k}$ & (2) & \multirow{4}{*}{$\begin{array}{l}\text { Suwon, } \\
\text { Sungnam in } \\
\text { Korea are } \\
\text { followed the } \\
\text { equation of } \\
\text { Europe. }\end{array}$} \\
\hline & Korea (9), Japan (14), & $\Gamma^{n} J^{k}$ & $(3)$ & \\
\hline & $\begin{array}{l}\text { USA (46), } \\
\text { Developing }\end{array}$ & $T_{k}=\frac{\sum_{1} \boldsymbol{I}_{i}}{\text { Total nonulation in city } k}$ & (3) & \\
\hline & countries (14) & Iolal populatoon in cily $\kappa$ & (3) & \\
\hline \multirow{4}{*}{$\begin{array}{c}\text { Modal } \\
\text { Share of PMM } \\
\text { (Private } \\
\text { passenger vehicle+ } \\
\text { Motorcycle) }\end{array}$} & $\begin{array}{c}\text { Europe (31), } \\
\text { Wealthy Asian (4) }\end{array}$ & $M_{k}^{r}$ & (3) & \multirow{4}{*}{$\begin{array}{c}\text { Private } \\
\text { passenger } \\
\text { vehicles, } \\
\text { includes taxies. }\end{array}$} \\
\hline & Korea $(9)$ & & (2) & \\
\hline & $\begin{array}{l}\text { Japan (14), USA (46), } \\
\text { Developing }\end{array}$ & $M_{k}^{r}=\left(\sum_{1}^{n}\left(I_{i}^{r, k}\right) / \sum_{1}^{n} I_{i}^{k}\right) \times 100$ & (3) & \\
\hline & countries $(14)$ & & (3) & \\
\hline \multirow{4}{*}{$\begin{array}{c}\text { Average } \\
\text { car occupancy of } \\
\text { passenger car }\end{array}$} & Korea (9), Europe (31), & & (3) & \multirow{4}{*}{ N/A } \\
\hline & $\begin{array}{l}\text { Wealthy Asian (4) } \\
\text { Develoning }\end{array}$ & $O_{k}^{r}$ & (2) & \\
\hline & (14) & & (2) & \\
\hline & Japan (14), USA (46) & $O_{k}^{r}=\sum_{1}^{n}\left(O_{i}^{r, k} \cdot I_{i}^{r, k}\right) / \sum_{1}^{n} I_{i}^{r, k}$ & (3) & \\
\hline
\end{tabular}

Note: $k=$ Cities $(k=1, \cdots, 119), i=$ Trip sample $(i=1, . ., n), l_{i}=$ Trip length of $i, d_{i}=$ travel time of $i, r=$ representative trip mode $(r=A, B, C ; A=P M M$, $B=P U B, C=N M M), L_{k}=$ Average trip length in city $k, V_{k}=$ Average vehicle speed in city $k, D_{i}^{r k}=$ Average travel time of trip $i$ by mode $r$ in city $k$, $T_{k}=$ Average daily trip number in city $k, M_{k}^{r}=$ Average modal share by mode $r$ in city $k, I_{i}^{r k}=$ Expansion factor of trip $i$ by mode $r$ in city $k$, $O_{k}^{r}=$ Average occupancy of mode $r$ in city $k$

\subsection{Classification of cities according to development of rail systems}

To understand the impact of the diversity of urban transport and infrastructure, as shown Table 3, this research classifies the target areas by the development of rail systems around the world. Rail transit has come into the spotlight for realizing transit oriented development, providing a good service on transportation, and reducing transportation energy consumption. Many researchers suggested that there is abundant evidence that high quality, grade-separated transit does reduce urban traffic congestion, and that transit improvements can be cost effective investments. Especially, Metro and Tram system are represented as major delegates of rail transit that being in charge of urban mobility. The metro, known as the subway or tube, is the optimal public transport mode for a high capacity (above 50,000 passenger per hour per direction is possible) line or network service. The tram system is the ideal modes carrying between 3,000 and 11,000 passengers per hour per direction in much narrower rights-of-way, and also producing no emissions at street level. In this way, Metro and Tram systems have shown that it can reduce the automo- 
Table 3 City classification according to rail systems

\begin{tabular}{cccccc}
\hline City classification & Type I & Type II & Type III & Type IV & Type V \\
\hline $\begin{array}{c}\text { Development of rail } \\
\text { systems }\end{array}$ & No railway (only Road) & (Metro + Tram) only & Metro only & Tram only & Excluding Metro, Tram \\
\hline
\end{tabular}

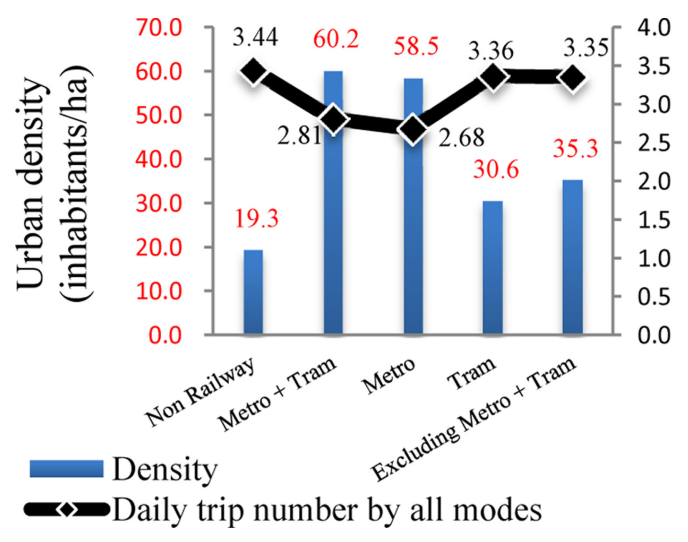

Fig. 1 Relationship between density and daily trip number

bile dependence in urban environments and has many positive attributes that benefit a town or city (UITP, 2001).

In this context, this research categorizes cities into five types by the development level of railway systems: Nonrailway, Metro + Tram, Metro only, Tram only, excluding Metro and Tram.

Then, this research considers the relationship between urban density and travel behaviors from the viewpoint of development of rail systems.

Finally, we examine how the efficiencies of transportation energy consumption, interacting with GRDP, trips by private motorized modes and public modes, are differ by the level of railway systems.

\section{Difference of Travel behaviors and Efficiencies on Transportation Energy Consumption According to Rail Systems}

\subsection{Relationship between urban density and travel behaviors according to rail system}

This research first presented relationship between urban density and travel behaviors on the PMM and the Public modes according to the level of the rail systems. Specifically, we focused on the features of variables indicating travel behaviors which included in estimation of the transportation energy consumption (trip number, trip speed and trip length) as above Fig. 1 to 5 .

Fig. 1 shows that higher urban density yields fewer daily trip numbers on average. Especially, in the case of the rail systems in Type II and Type III, the trip number is quite

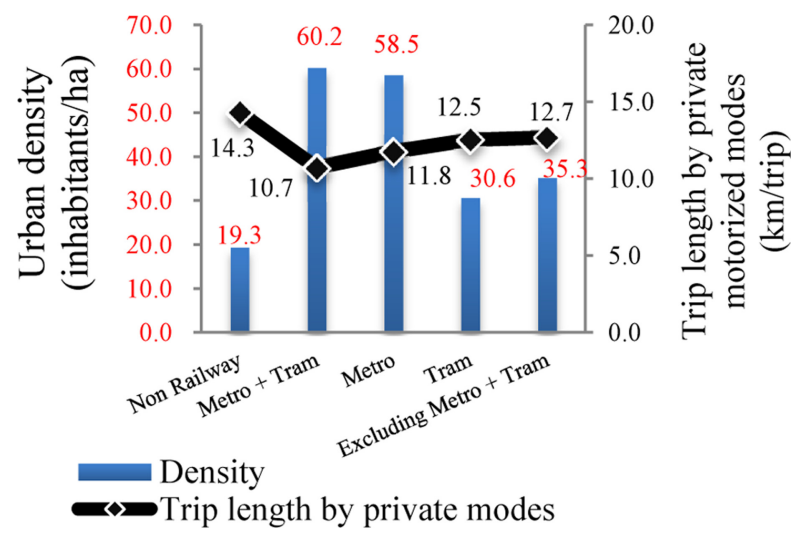

Fig. 2 Relationship between density and trip length by private motorized modes

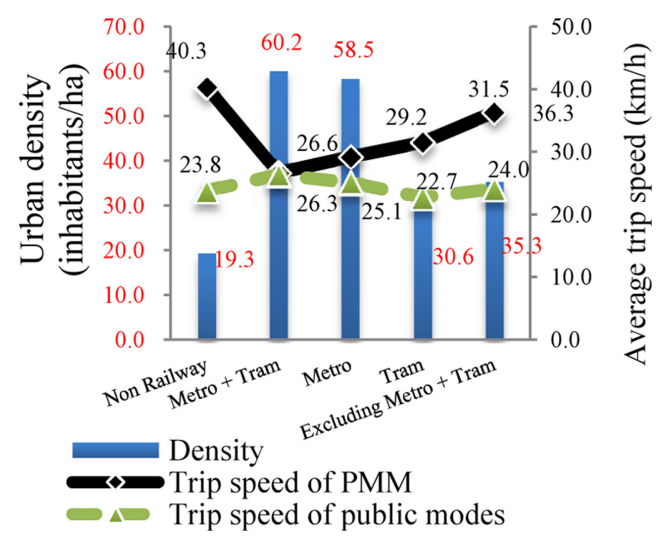

Fig. 3 Relationship between density and average speed of PMM, public modes

low (2.81 trips/day/person in Type II, 2.68 trips/day/person in Type III) compared to other cities. This shows that the trip number in Type II rail system is the lowest under the highest urban density (60.2 inhabitants/ha).

Next, Fig. 2 reveals that higher urban density is favorable for shorter trips by the PMM. Particularly, the Type II rail system under the highest urban density generally makes trip length shorter $(10.7 \mathrm{~km} /$ trip$)$. In this context, Giuliano and Dhiraj (2003) built the regression model interpreting daily trip number and average trip distance in cities by applying the characteristics of the socio-economic and urban structure. Their result shows that the urban structure has significant effect on travel behaviors and there is a divergence of results. In general, the daily 


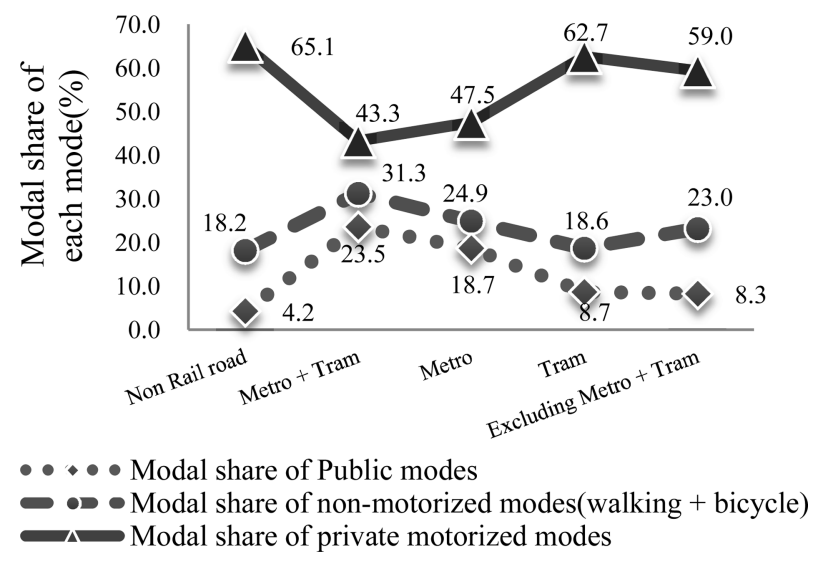

Fig. 4 Modal share of all modes

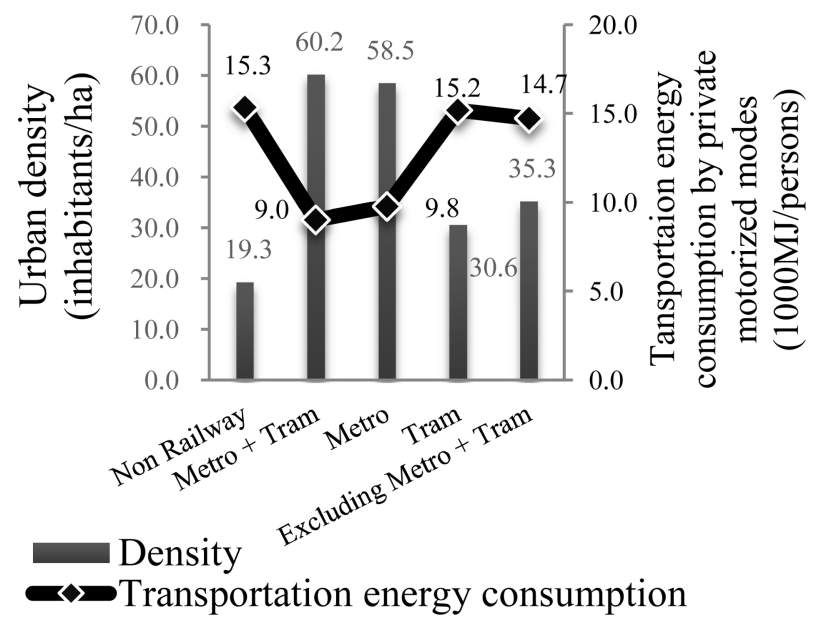

Fig. 5 Relationship between density and transportation energy consumption

trip number depends on the urban scale. The larger the urban area is, the less daily trip number is generated.

In addition, the trip distance is substantially significant with urban density, and the denser the urban structure is, the shorter the trip distance is. Fig. 3 shows the trip speed of the PMM and the public modes. In general, the speed of the PMM is slower and the speed of the public modes is faster under denser urban structure. Especially, the feature of the Type II in which the trip speed of the PMM is the slowest $(26.6 \mathrm{~km} / \mathrm{h})$ and the speed of the public modes is the fastest $(26.3 \mathrm{~km} / \mathrm{h})$ is outstanding. These results from Fig. 3 intensely show that denser urban structure influences travel behavior on PMM and public modes. Also, it could be conjectured that there is a relationship between denser urban structure and the travel pattern for public transport such as metro or tram.

In this context, Fig. 4 shows the ratio of the modal share according to the PMM, public modes and Non-Motorized
Modes (NMM). From here, it is possible to figure out that the modal choice for public modes and NMM are often made under the urban condition of having a railway system. Especially, the condition of the Type II restrains the use of PMM but revitalizes the use of public modes and NMM.

Therefore, it could be conjectured that development of established rail network such as link of Metro and Tram would absorb travel demands. Moreover, depending on the development of railway system, space management could be properly maintained for pedestrians or bicycle riders. Fig. 4 demonstrates that denser urban structure limits the usage of the passenger cars and promotes higher demand for public modes and walking, bicycling. In addition, the specific effect of denser urban structure appears under Type II rail system. Considering all relations between urban density and travel behaviors above, transportation energy consumption is lower under denser urban structure with an established rail system such as Type II or Type III as shown in Fig. 5.

\subsection{Definition on efficiency of transporta- tion energy consumption}

We define the efficiency of transportation energy consumption in this research as creating more value with less environmental impact on the PMM. Efficiency was evaluated on the basis of two aspects: the economic level and the travel behavior. In this context, this research attempted to observe how much GRDP and trips by private motorized modes and public modes are created by transportation energy consumption of the PMM, which implies the result from the production activity in a city. The maximum efficiency is 1 , which indicates a city creating the most multi-value with less transportation energy consumption of the PMM.

\subsection{Estimation method for efficiency of transportation energy consumption}

Data Envelopment Analysis (DEA) is a nonparametric method in operations research for an estimation of efficiency. It is used to measure empirically the efficiency of decision making units (DMUs). This allows a best-practice relationship between multiple outputs and multiple inputs to be estimated. DMU is the subject of evaluation and the efficiency of DMU is calculated by the ratio scale of (output / input). If there are many entities with similar results, it is possible to make a comparison between them with the relative magnitude of the ratio scale. In addition, evaluation by a changeable weight that ignores the unit of individual variable is possible. However, DEA does not provide a general relationship between output and input. Furthermore, this evaluation method is not for absolute evaluation of efficiency but is for the relative comparison analysis between entities. 
Therefore, in carrying out DEA on the efficiency of the transportation energy consumption, one needs to understand the theoretical relationship between the urban-transportation factors on reading analyzed results. Thus, this research utilizes DEA as only an estimation method for comparative analysis on the energy efficiency.

The Charnes Cooper Rhodes (CCR) model can be quoted as the most basic models of DEA. DMUs has a number of $\mathrm{N}$, and when there are $\mathrm{m}$ of individual inputs and $\mathrm{s}$ of outputs, a virtual input and output are defined by equation (7), (8). Here, put a weight that can be advantageous to DMUs on the input and output. However, the efficiency is represented by a virtual output / virtual input, and maximum weight is 1 so that it does not take a negative value. The following formula is a fractional programming equation. The optimal solution obtained from here is $\left(v^{*}, u^{*}\right)$, and the case of $\theta^{*}$ is the objective function. If $\theta^{*}=1: \mathrm{MDU}_{0}$ is effective, if $\theta^{*}<1: \mathrm{MMU}_{0}$ is ineffective.

The weights are obtained from each input value in the entire input on the denominator, and it is called a weighted input value. In the same way, the value on the numerator of DMU is called a weighted output value.

A virtual input $\Theta_{i}=v_{1} \times$ input $1+v_{2} \times$ input 2

$$
+\ldots+v_{\mathrm{m}} \times \text { input } m
$$

A virtual output $\Theta_{o}=u_{1}$ output $1+u_{2} \times$ output $2+\ldots+u_{\mathrm{s}}$ output $\mathrm{s}$

Objective function $\theta^{*}=\frac{u_{1} y_{1}+u_{2} y_{2}+\ldots+u_{s} y_{s}}{v_{1} x_{1}+v_{2} x_{2}+\ldots+v_{m} x_{m}}$

Constraints $\frac{u_{1} y_{1}+u_{2} y_{2 j}+\ldots+u_{s} y_{s j}}{v_{1} x_{1 y}+v_{2} x_{2 j}+\ldots+v_{m} x_{m j}} \leq 1$

$$
(j=1, \ldots, n) \ldots
$$

$v_{1}, v_{2}, \ldots, v_{m} \geq 0$

$u_{1}, u_{2}, \ldots, u_{m} \geq 0 \ldots$

\subsection{Estimation of the efficiency of transportation energy consumption}

This research estimates the efficiency of transportation energy consumption. The efficiency of transportation energy consumption means the ratio between the combination of GRDP, trips by PMM, public modes and the transportation energy consumption. For this, a changeable weight was imposed on the input and output variables for DEA estimation. The efficiency $=1.0$ means a Frontier that DMU is relatively the most desirable city on the basis of the efficiency of the transportation energy consumption. As mentioned earlier, the efficiency from DEA does not show the relationship between urban-transportation factors. Therefore, we clarified a relationship between the urban density and the travel behaviors before utilizing DEA. Based on the findings above Fig. 1 to 5, we next examine the efficiency of the transportation energy consumption by considering target cities. And then the result was classified by the level of the rail systems as shown in Table 4, Table 5 and Fig. 6. Fig. 6, and Table 4 show the results of DEA analysis on the efficiencies of 119 cities in Asia, Europe, USA and developing countries. And the result of DEA is classified by the development of the rail systems. As shown in Fig. 6, an inverse relation between the energy efficiency and the energy consumption is observed. The efficiency ranges from 0.061 (Columbus) to 1 (Osaka, Hong Kong, Phnom Penh). Generally, the efficiency in cities of the USA of Type I which have low density is low.

Meanwhile, the cities with denser urban structure, longer railways, combination rail systems and high modal share by the public modes (i.e., Tokyo, Fukuoka, Vienna, Hong Kong, Lima) show higher efficiencies of the transportation energy consumption. Table 5 reveals that the average efficiency of transportation energy consumption is 0.3287 (Type II), 0.3086 (Type III), 0.2110 (Type V), 0.2106 (Type I) and 0.1806 (Type IV) in the order of the level of the rail system, showing high efficiency. In Fig. 6, the urban types having rail systems broadly indicate higher

\begin{tabular}{|c|c|c|c|c|c|c|c|c|c|c|c|}
\hline $\begin{array}{c}\text { Urban } \\
\text { Area }\end{array}$ & Type & $\begin{array}{c}\text { Efficiency of } \\
\text { transportation } \\
\text { energy } \\
\text { consumption }\end{array}$ & $\begin{array}{l}\text { Transportation } \\
\text { energy } \\
\text { consumption }\end{array}$ & $\begin{array}{l}\text { Urban } \\
\text { Area }\end{array}$ & Type & $\begin{array}{c}\text { Efficiency o } \\
\text { transportatio } \\
\text { energy } \\
\text { consumptio }\end{array}$ & $\begin{array}{l}\text { ansportation } \\
\text { energy } \\
\text { nsumption }\end{array}$ & $\begin{array}{l}\text { Urban } \\
\text { Area }\end{array}$ & Type & $\begin{array}{c}\text { Efficiency of } \\
\text { transportation } \\
\text { energy } \\
\text { consumption }\end{array}$ & $\begin{array}{c}\text { Transportation } \\
\text { energy } \\
\text { consumption }\end{array}$ \\
\hline Charlotte & I & 0.229 & 17,816 & Vienna & II & 0.405 & 6,483 & Inchon & III & 0.237 & 7,372 \\
\hline Houston & I & 0.168 & 18,692 & Amsterdam & II & 0.251 & 7,591 & Daejeon & III & 0.225 & 6,425 \\
\hline Indianapolis & I & 0.164 & 19,725 & Rotterdam & II & 0.182 & 9,428 & Pusan & III & 0.242 & 8,231 \\
\hline Milwaukee & I & 0.189 & 15,596 & Lyons & II & 0.212 & 10,518 & Kwangju & III & 0.216 & 7,359 \\
\hline Columbus & I & 0.061 & 39,980 & Rome & II & 0.156 & 12,156 & Suwon & III & 0.177 & 9,781 \\
\hline Kansas City & I & 0.160 & 21,534 & Brussels & II & 0.167 & 11,828 & Athens & III & 0.161 & 9,169 \\
\hline
\end{tabular}

Table 4 Efficiencies on transportation energy consumption 
Table 4 Continued

\begin{tabular}{|c|c|c|c|c|c|c|c|c|c|c|c|}
\hline $\begin{array}{l}\text { Urban } \\
\text { Area }\end{array}$ & Type & $\begin{array}{l}\text { Efficiency of } \\
\text { transportation } \\
\text { energy } \\
\text { consumption }\end{array}$ & $\begin{array}{l}\text { Transportation } \\
\text { energy } \\
\text { consumption }\end{array}$ & $\begin{array}{l}\text { Urban } \\
\text { Area }\end{array}$ & Type & $\begin{array}{c}\text { Efficiency of } \\
\text { transportation } \\
\text { energy } \\
\text { consumption }\end{array}$ & $\begin{array}{l}\text { Transportation } \\
\text { energy } \\
\text { consumption }\end{array}$ & $\begin{array}{l}\text { Urban } \\
\text { Area }\end{array}$ & Type & $\begin{array}{l}\text { Efficiency of } \\
\text { transportation } \\
\text { energy } \\
\text { consumption }\end{array}$ & $\begin{array}{l}\text { Transportation } \\
\text { energy } \\
\text { consumption }\end{array}$ \\
\hline Kansas City & I & 0.160 & 21,534 & Brussels & II & 0.167 & 11,828 & Athens & III & 0.161 & 9,169 \\
\hline Austin & I & 0.166 & 18,045 & Lille & II & 0.189 & 10,754 & Daegu & III & 0.194 & 7,714 \\
\hline $\begin{array}{l}\text { Nashville- } \\
\text { Davidson }\end{array}$ & I & 0.152 & 23,291 & Berlin & II & 0.279 & 7,874 & Sungnam & III & 0.290 & 8,613 \\
\hline Ulsan & I & 0.198 & 9,785 & Lisbon & II & 0.232 & 6,193 & Sao Paulo & III & 0.303 & 4,428 \\
\hline Orlando & I & 0.170 & 17,618 & Prague & II & 0.503 & 7,706 & $\begin{array}{c}\text { Kuala } \\
\text { Lumpur }\end{array}$ & III & 0.141 & 9,221 \\
\hline Cincinnati & I & 0.162 & 20,586 & Valencia & II & 0.146 & 7,965 & Lima & III & 0.881 & 2,348 \\
\hline Phoenix & I & 0.166 & 17,495 & Warsaw & II & 0.524 & 5,077 & Damascus & III & 0.938 & 1,548 \\
\hline Louisville & I & 0.173 & 17,737 & Budapest & II & 0.360 & 8,197 & Seattle & IV & 0.153 & 22,623 \\
\hline Rochester & I & 0.177 & 17,288 & Moscow & II & 0.495 & 6,251 & Hiroshima & IV & 0.225 & 7,524 \\
\hline Honolulu & I & 0.196 & 13,552 & Bucharest & II & 0.448 & 6,713 & Zurich & IV & 0.252 & 11,013 \\
\hline Norfolk & I & 0.122 & 26,343 & Cairo & II & 0.302 & 7,747 & Portland & IV & 0.149 & 17,287 \\
\hline $\begin{array}{l}\text { Oklahoma } \\
\text { City }\end{array}$ & I & 0.202 & 13,237 & Nagoya & III & 0.314 & 6,812 & New Orleans & IV & 0.145 & 20,240 \\
\hline Providence & I & 0.158 & 17,510 & Washington & III & 0.149 & 21,476 & Memphis & IV & 0.115 & 22,357 \\
\hline San Antonio & I & 0.164 & 15,790 & Boston & III & 0.181 & 18,437 & Turin & IV & 0.198 & 8,447 \\
\hline Jacksonville & I & 0.130 & 26,915 & Fukuoka & III & 0.280 & 6,279 & Melbourne & IV & 0.139 & 17,002 \\
\hline Dubai & I & 0.165 & 11,005 & New York & III & 0.196 & 12,931 & Manchester & IV & 0.189 & 10,222 \\
\hline Hartford & I & 0.106 & 22,352 & Atlanta & III & 0.154 & 20,591 & Denver & V & 0.153 & 22,422 \\
\hline Tripoli & I & 0.477 & 2,445 & Chicago & III & 0.197 & 14,113 & Dallas & V & 0.161 & 18,703 \\
\hline Chengdu & I & 0.251 & 1,747 & Los Angeles & III & 0.178 & 16,217 & $\begin{array}{c}\text { Minneapolis- } \\
\text { St. Paul }\end{array}$ & V & 0.108 & 30,467 \\
\hline Ho Chi Minh & I & 0.135 & 8,252 & Sendai & III & 0.255 & 7,116 & $\begin{array}{l}\text { Salt Lake } \\
\text { City }\end{array}$ & V & 0.199 & 14,041 \\
\hline Hanoi & I & 0.239 & 899 & Kyoto & III & 0.401 & 3,397 & Detroit & V & 0.172 & 17,229 \\
\hline Jakarta & I & 0.266 & 4,971 & Cleveland & III & 0.083 & 33,645 & Chiba & V & 0.416 & 4,892 \\
\hline Managua & I & 0.331 & 5,276 & Kobe & III & 0.332 & 4,238 & San Diego & $\mathrm{V}$ & 0.151 & 19,691 \\
\hline Nairobi & I & 0.096 & 3,857 & Baltimore & III & 0.130 & 21,476 & St. Louis & V & 0.138 & 20,056 \\
\hline Phnom Penh & I & 1.000 & 817 & Miami & III & 0.156 & 15,488 & Pittsburgh & V & 0.103 & 22,706 \\
\hline Osaka & II & 1.000 & 2,148 & Yokohama & III & 0.396 & 5,304 & Kitakyushu & $\mathrm{V}$ & 0.183 & 8,298 \\
\hline Tokyo & II & 0.796 & 3,548 & Saitama & III & 0.458 & 4,001 & Copenhagen & $\mathrm{V}$ & 0.201 & 10,306 \\
\hline $\begin{array}{c}\text { San } \\
\text { Francisco }\end{array}$ & II & 0.176 & 19,197 & Singapore & III & 0.374 & 8,139 & Kawasaki & V & 0.666 & 3,305 \\
\hline Munich & II & 0.189 & 14,397 & Hong Kong & III & 1.000 & 2,562 & Sacramento & V & 0.127 & 21,761 \\
\hline Oslo & II & 0.245 & 10,908 & Glasgow & III & 0.177 & 11,084 & Stuttgart & V & 0.169 & 13,514 \\
\hline Philadelphia & II & 0.162 & 18,738 & Bilbao & III & 0.184 & 6,942 & Tampa & V & 0.134 & 20,230 \\
\hline Paris & II & 0.246 & 9,187 & Seoul & III & 0.846 & 2,438 & Buffalo & V & 0.163 & 15,331 \\
\hline Helsinki & II & 0.352 & 7,851 & Madrid & III & 0.195 & 10,719 & Seville & $\mathrm{V}$ & 0.150 & 6,670 \\
\hline London & II & 0.235 & 9,560 & Newcastle & III & 0.199 & 8,956 & Manila & V & 0.231 & 5,298 \\
\hline Sapporo & II & 0.294 & 6,191 & Barcelona & III & 0.196 & 6,934 & & & & \\
\hline
\end{tabular}


Hyunsu Choi, Dai Nakagawa, Ryoji Matsunaka, Tetsuharu Oba and Jongjin Yoon / IJR, 6(2), 33-44, 2013

Table 5 Characteristic on travel behaviors, efficiency of energy consumption and transportation energy consumption

\begin{tabular}{|c|c|c|c|c|c|c|}
\hline \multicolumn{2}{|c|}{ Variables } & Non Railway & Metro \&Tram & Metro & Tram & Excluding Metro \& Tram \\
\hline \multicolumn{2}{|c|}{ Urban density (inhabitants/ha) } & 19.3 & 60.2 & 58.5 & 30.6 & 3.3 \\
\hline \multicolumn{2}{|c|}{ Daily trip number(trips/day) } & 3.44 & 2.81 & 2.68 & 3.36 & 3.35 \\
\hline \multicolumn{2}{|c|}{ Average trip distance of PMM (km/trip) } & 14.3 & 10.7 & 11.8 & 12.5 & 12.7 \\
\hline \multirow{2}{*}{$\begin{array}{l}\text { Average trip speed } \\
\qquad(\mathrm{km} / \mathrm{h})\end{array}$} & PMM & 40.3 & 26.3 & 26.6 & 29.2 & 31.5 \\
\hline & PUB & 23.8 & 26.3 & 25.1 & 22.7 & 24.0 \\
\hline \multirow{3}{*}{$\begin{array}{l}\text { Modal Share } \\
\quad(\%)\end{array}$} & PMM & 65.1 & 43.3 & 47.5 & 62.7 & 59.0 \\
\hline & PUB & 4.2 & 23.5 & 18.7 & 8.7 & 8.3 \\
\hline & NMM & 18.2 & 31.3 & 24.9 & 18.6 & 23.0 \\
\hline \multicolumn{2}{|c|}{$\begin{array}{l}\text { Transportation energy consumption } \\
\text { (MJ/person/year) }\end{array}$} & 15,340 & 9,008 & 9,764 & 15,190 & 14,731 \\
\hline \multicolumn{2}{|c|}{ Energy efficiency } & 0.2106 & 0.3287 & 0.3086 & 0.1806 & 0.2110 \\
\hline
\end{tabular}

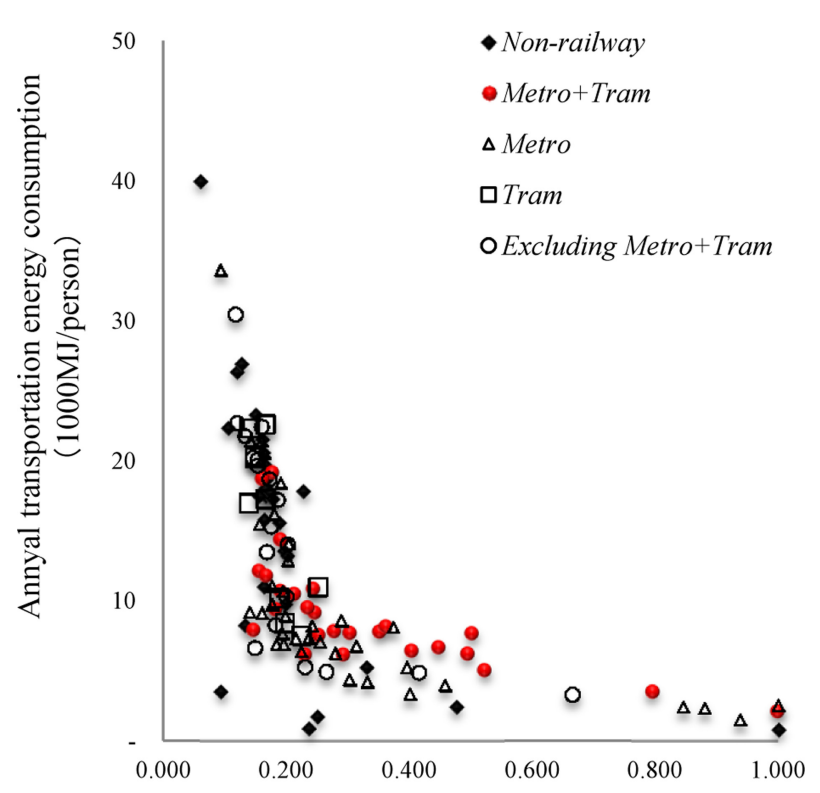

Efficiency of transportation energy consumption

Fig. 6 Relationship between efficiency of energy consumption and transportation energy consumption

efficiency on transportation energy consumption than Type I having non-rail system. The efficiencies of Type II having Metro + Tram and Type III having Metro are particularly outstanding. Here, Type I and Type V including many US cities in which urban density is quite low show almost same efficiency.

In Fig. 6 and Table 5, one of the urban type that shows the lowest efficiency next to Type IV is Type I with no rail system. From Fig. 1 to 5, the highest trip generation, the longest trips, the slowest trip speed of public modes and the highest energy consumption are observed for Type I. Choi et al, (2011) demonstrated that the longer trip, the more trips generation under lower density such as Type I including the US cities. And also, it is possible to deduce that the efficiency of transportation energy consumption does not become effective under low urban density on the contrary to Type II and Type III including DUMs which the efficiency is 1 as shown Fig. 6. Meanwhile, Phnom Penh (1.000), Tripoli (0.477), Managua (0.331) in Type I show relatively high energy efficiency as shown in Table 4 even if they are non-railway type for which the common trend of economic level (GRDP) in these cities is quite low. From this result, it is possible to conjecture that people have to rely on the public modes due to less car ownership under low economic status. In this context, the high modal share of the public transport in the above cities could affect the result that the energy efficiency is high due to the adjustable weight of the DEA model. Meanwhile, the efficiency of Type IV is the lowest relative to other the rail systems and Type I. According to Fig. 3, 4 and 5 as shown above, Type IV, with only tram, shows the slowest trip speed of the public modes, the highest modal share of the PMM and transportation energy consumption among urban types having a rail system even though the rail system is constructed. Especially, the urban density (30.6 inhabitants/ha) of Type IV is the lowest among the urban types having the rail system. This might mean that the rail system under low density does not show the correlation between a rail network and restraining usage, energy consumption of the PMM.

\section{Conclusion}

This research built a database of 119 cities concerning transportation energy consumption of the private motorized modes, and it reflects individual travel behaviors cal- 
culated by Person Trip data. In addition, we established the relationship between urban density and travel behaviors before utilizing DEA that considers the diversity of urbantransport features. Consequently, we clarified that denser urban structure, with well-maintained railway system (such as Metro + Tram), could divert the private vehicle users to the public transport, hence decrease the transportation energy consumption, and encourage NMM. Therefore, it seems that denser urban structure and wellconstructed railway systems have meaningful relationship with realizing higher efficiency of transportation energy consumption.

The results provide practical and reliable information related to reducing transportation energy consumption through the propensities of travel behaviors and efficiencies on energy consumption. Furthermore, understanding the relations between urban structure and travel behaviors according to the level of railway systems will be invaluable for measures to reduce energy consumption in urban development planning.

\section{Notes}

1. KTDB: Korean Transport Database. MLITT: Ministry of Land. Infrastructure. Transport and Tourism. JICA: Japan International Cooperation Agency. UITP: International Association of Public Transportation. FHWA: Federal Highway Administration U.S. Department of Transportation

2. Korea: Population and housing census (2005). Wealthy Asian: Periodic surveys(censuses. mobility studies) of International Association of (UITP)2001. countries: The study on master plan for urban transport in the metropolitan area-(Cairo. Tripoli.(2001); Phnom Penh. Belem. Chengdu. Jakarta. Kuala Lumpur(2000); Damascus. Managua(1998); Manila(1997); Bucharest(1999); Lima. Hanoi(2005); Ho Chi Minh(2003); Nairobi(2004))

3. Korea: Household Travel Survey((2005)-Inchon. Suwon. Sungnam (2006)). Japan: The Nationwide Person Trip Survey(2005). U.S.A: NHTS(National Household Travel Survey. 2001). Developing countries: Household Interview Survey of each country-(Cairo. Tripoli.(2001); Phnom Penh. Belem. Chengdu. Jakarta. Kuala Lumpur(2000); Damascus. Managua(1998); Manila(1997); Bucharest(1999); Lima. Hanoi(2005); Ho Chi Minh(2003); Nairobi(2004))

4. Korea: The Statistics Report of each city(2005). Japan: The Statistics Report of each city(2005). U.S.A: U.S. Department of Transportation. Federal Highway Administration. Highway Statistics 2001

5. U.S.A: Regional Economic Accounts Bureau of Eco- nomic Analysis U.S. Department of Commerce

6. All of vehicle in this research is assumed as gasoline vehicles

7. Fuel efficiency of motorcycle is assumed a half of passenger car

\section{References}

1. Ahmad, A., Fujiwara A. and Zhang, J., (2009). "A DEA analysis of energy consumption in transport sector and carbon dioxide emissions in selected 85 countries of the world", CD-ROM, Proceeding of Infrastructure Planning, Vol. 39.

2. Aratani, T. and Todoroki, T., (2009). "An analysis on intercity mobility by public transportation service using data environment analysis", Committee of Infrastructure Planning and Management, No. 39 in Japanese.

3. Choi, H., Nakagawa, D., Matsunaka, R. and Oba, T., (2011). "Building a database of transportation energy consumption in cities of the world with information related to travel behavior", Journal of International City Planning 2011, pp. 263-272.

4. Choi, H., Nakagawa, D., Matsunaka, R. and Oba, T., (2012). "International research on the relationship between urban structure and transportation energy consumption according to economic level", The Australian Journal of Regional Science, Vol. 18, No. 1, pp. 128-149.

5. Feng, T., Zhang, J. and Fujiwara, A., (2007). Environmental Efficiency Analysis of Transportation System: A Stochastic Frontier Approach with Flexible Cause-Effect Structure, Journal of the EASTS, Vol. 7, pp. 1475-1489.

6. Giuliano, G. and Dhiraj, N., (2003). "Another look at travel patterns and urban form: The US and great britain", Urban Studies, Vol. 40, No. 11, pp. 2295-2312.

7. Kenworthy, J.R., Laube, F.B., Newman, P.W.G., Bater, P.A., Raad, T., Poboon, C. and Guia, B., (1999). "An international sourcebook of automobile dependence in cities 19601990", University Press of Colorado, Boulder, Co.

8. Matsuhashi, K., Kudoh, Y., Kamioka, N. and Moriguchi, Y., (2004). "A study on estimation method for transport $\mathrm{CO}_{2}$ emissions by municipalities", Environmental System Analysis and Research, Vol. 32, pp. 235-242 in Japanese.

9. Morimoto, A., (2002). "A research review on compact city in terms of transportation environmental load", CD-ROM, Proceeding of Infrastructure Planning, Vol. 25 in Japanese.

10. Morimoto, A. and Koike, H., (1995). "A comparison of the urban structure impact upon transportation energy", Journal of the City Planning Institute of Japan, No. 30, pp. 685-690 in Japanese.

11. Oshiro, Y., Matsushita, M., Namikawa, R. and Onish, H. (2001). "Fuel consumption rate and a carbon dioxide discharge coefficient in a vehicle travel", Civil Engineering Journal, Vol. 43 No. 11, pp. 50-55 in Japanese.

12. Taniguchi, M., Matsunaka, R. and Hirano, M. (2008). "Time-Series Analysis of the Relationship between Urban 
Layout and CO_2 Emission by Automobile", Journal of the City Planning Institute of Japan Vol. 43, No. 3, pp. 121-126 in Japanese.

13. Yoshino D., Fujiwara, A. and Zhang J. (2010). "Environmental efficiency model based on data envelopment analysis and its application to environmentally sustainable transport policies", Journal of the Transportation Research
Board, Vol. 2163, pp. 112-123.

14. Nakamura, H., Giuliano, G., Sperling, D., May, A., D, Miyamoto, K., Rithengatter, W. (Eds.). (2004). "Urban Transport and the Environment-An International Perspective", World Conference on Transport Research Society and Institute for Transport Policy Studies. Amsterdam: Elsevier. 